\title{
Study on Communal Wastewater Treatment Plants (CWWTPs) in Gresik, Indonesia
}

\author{
Eddy S. Soedjono ${ }^{1}$, Nurina Fitriani ${ }^{2, *}$, Arif Setiawan ${ }^{3}$, Gelora J. T. Mulia ${ }^{4}$, Dwi \\ A. Ningsih ${ }^{1}$
}

${ }^{1}$ Department of Environmental Engineering, Institut Teknologi Sepuluh Nopember, 60111 Surabaya, INDONESIA

${ }^{2}$ Study Program of Environmental Engineering, Department of Biology, Universitas Airlangga, 60115 Surabaya, INDONESIA

${ }^{3}$ Wastewater Integrated Services Unit (UPT), Local Government of Gresik Regency, INDONESIA

${ }^{4}$ Department of Environmental Health,

Universitas Indonesia, 16424 Jakarta, INDONESIA

*Corresponding Author

DOI: https://doi.org/10.30880/ijie.2019.11.01.025

Received 07 July 2018; Accepted 12 December 2018; Available online 15 May 2019

\begin{abstract}
Communal wastewater treatment plants (CWWTPs) with sewer system has been built by local government in Gresik Regency to achieve sanitation strategy by 2012-2016. There are seven CWWTPS in Gresik; Bedilan, Singosari 1, Roomo, Sidorukun, Karangturi, Singosari 2, and Singosari 3. Each of CWWTP is maintained by the community and known as KPP (Kelompok Pengguna Pemelihara or community group of users and maintainers). CWWTPs have some operational problems due to minimum maintenance. Therefore, evaluation of CWWTPs is needed to determine whether field maintenance program complies with the guidelines. Efficiency in term of BOD removal for the 7 CWWTPs is between 79-96\% and it complies with design criteria; except Bedilan CWWTP where removal of COD is $52.7 \%$ and it could not comply with the design criteria while removal of oil and grease is only up to $13 \%$. One of the reasons for these failure was due to poor monitoring. Local communities have poor understanding regarding the duties and functions of KPP due to little information regarding KPP in the villages.
\end{abstract}

Keywords: Wastewater treatment plants

\section{Introduction}

Universal access for sanitation is one of Sustainable Development Goals (SDG's) targets which has to be achieved by 2030 [1]. Access to sanitation has not changed significantly in Indonesia in the reformation era [2]. Based on World Bank studies, household without adequate sanitation facilities in Indonesia discards 6.4 million tons of feces into open drainage system each year [3]. The universal access of sanitation in Indonesia has been accommodated in National MidYear Plan (RPJMN) 2014-2019. Local government of Gresik Regency started to prepare its sanitation strategies or SSK in 2011 as part of the national sanitation development [4]. The objectives and stages of sanitation achievement strategy in Gresik 2016-2020 are to increase the number of CWWTPs and its services area up to 50 units in 3 slum areas, CWWTPs at industrial houses for up to 30 units, while the 2 units of CWWTPs running at district scale are well maintained [5]. Local government of Gresik has built 46 CWWTPs with sewer system funded by Public Works Agency 
(PU) through USRI (Urban Sanitation and Rural Infrastructure) program and activity allocation fund (DAK) at three districts;Gresik, Kebomas, and Manyar between 2011-2013. The aim of this sanitary facility development is simply to provide the communities in order not to defecate in the open practice. Unfortunately, although these facilities have been constructed, CWWTPs are not running properly due to lack of maintenance by KPP [6]. Based on the field observations, it is known that effluent of CWWTP is not regularly monitored. Evaluation is needed to improve quality of services to the community and to determine whether the program has reached the RPJMD target [7]. The option of reusing treated wastewater is becoming necessary for environment sustainability approach. In fact, wastewater regulations of effluent discharge have become stricter leading to a better water quality [8].

Evaluation is a systematic process of collecting, analyzing, and interpreting information to assess the achievement of the government programs for public services. Sustainable sanitation system should be reasonable to build, operate, and maintain [9]. Appropriate institutional aspect should be designed to manage the sanitation systems, from infrastructure up to operation and maintenance to make sustainable systems [10]. One of the institutional problems in domestic wastewater treatment in is lack of involvement of local government agency in wastewater management [11].

\subsection{Communal wastewater treatment plants (CWWTPs)}

Anaerobic Baffled Reactor (ABR) is the technology development of septic tank. Partition walls in ABR force wastewater input to flow along the paths and make the retention time much longer than septic tank and creates improvement of the biological processes. ABR provides BOD removal between 70-95\%. ABR needs vent because it produces methane and it takes 3 months to stabilize the biomass at the beginning of the process [12]. Advantages of ABR are [13]:

- Low cost in construction, simple design, no mechanical mixer, reduce clogging, and it minimize sludge.

- No biomass with special sedimentation, low sludge production, and high solid retention time.

- Low hydraulic retention time, allow intermittent operation, protection from influent toxic, longer operation and high stability on organic shock loading.

KPP operates and looks after CWWTPs and it consists of community groups who have been involved in the planning and construction of sanitation infrastructure. KPP is assigned to collect retribution, record and report transactions, operation and maintenance of physical infrastructure, routinely control the pipeline infrastructure, improve quality service and network expansion, carry out education and campaigns for community health [14]. Construction was initiated with focus group discussion and in-depth interview to locate the proper location to be triggered [15].

\section{Material and method}

\subsection{Communal wastewater treatment plants (CWWTPs)}

Primary and secondary data have been collected to support this study. Primary data were samples of domestic wastewater and questionnaires from respondents. Questionnaires were addressed to KPP as management of CWWTPs. Respondent were selected in seven WWTPs in Gresik Regency. Questionnaires were addressed to analyze attitude, confidence, behaviors, and characteristics of the community in certain environments [16]. Number of respondents were determined from the formula from Ministry of Public Works regulation number 18/PRT/M 2007 regarding Water Supply Systems [17].

$$
\begin{gathered}
n=\frac{N p(1-p)}{(N-1) D+p(1-p)} \\
D=\frac{B^{2}}{t^{2}}
\end{gathered}
$$

where: $n=$ number of samples, $N=$ number of population (house hold), $p=$ element ratio in the sample that have desirable properties $(0,5), B=$ allowable error rate for each sample $5 \%$, and $t=$ level of confidence $(1-B)$

\subsection{Data collection}

Data collection are divided into two sources namely the primary and secondary. Primary data collection is to obtain actual conditions. The steps to collect primary data are:

- Conduct interviews to management of CWWTP or KPP (group of users and maintainer). KPP is responsible for the operation and maintenance of CWWTP.

- Water quality from 7 CWWTPs effluent discharge was collected and analysis was conducted in Environmental Engineering Department-ITS for BOD, COD, TSS, pH, oil and grease in inlet and outlet of CWWTP. Selected 7 CWWTPs in Gresik were Bedilan, Singosari 1, Roomo, Sidorukun, Karangturi, Singosari 2, and Singosari 3. Data 
of water quality was compared with regulation from Ministry of Environmental and Forestry about Domestic Wastewater Standards No. 68, 2016.

- Sampling was collected from outlet of each WWTP for 7 samples. Collected water samples are put into sealed bottles to laboratory. Sampling and preservation method were following APHA (2012).

Meanwhile, secondary data consists of literature study, location of CWWTPs in Gresik, number of CWWTPs users, and monthly/annual report of CWWTPs.

\section{Results and Discussion}

\subsection{Analysis of Primary Data}

KPP members consist of the CWWTPs users who are selected by community itself to manage the plants. Operations and maintenance of CWWTPs are encouraged to involve women as they are the main users of CWWTPs. Therefore, management of KPP is at least $40 \%$ women [18]. The survey results indicate that the percentage of women personnel management in KPP Bulan Barat and KPP TulusIkhlas are less than 40\%. This is due to lack of public awareness especially women participation in CWWTP management; as the results, KPP is dominated by male.

\subsection{Field Observations}

The technology used in CWWTPs is combination between anaerobic baffled reactor (ABR) and anaerobic filter (AF). Physically, CWWTPs in study area are in good conditions. There are two CWWTPs in Kebomas District: Singosari 1 and Singosari 2. They were built in 2013 and made of concrete. Another CWWTP of Singosari 3 built in 2012 is now used as small community hall (Balai RW). CWWTPs from fiberglass are constructed in Manyar District: Sidorukun, Karangturi, Bedilan, and Roomo. Number of house connections are shown in Table 1.

Table 1 - The number of WWTP users

\begin{tabular}{ccccc}
\hline \multirow{2}{*}{$\begin{array}{c}\text { WWTP } \\
\text { location }\end{array}$} & The number of users (plan) & \multicolumn{2}{c}{$\begin{array}{c}\text { The number of users } \\
\text { (existing) }\end{array}$} \\
\cline { 2 - 5 } & House-holds & peoples & $\begin{array}{c}\text { House- } \\
\text { holds }\end{array}$ & peoples \\
\hline Singosari 1 & 89 & 365 & 57 & 226 \\
Singosari 2 & 50 & 200 & 61 & 213 \\
Singosari 3 & 76 & 312 & 94 & 354 \\
Bedilan & 60 & 256 & 57 & 228 \\
Karangturi & 75 & 300 & 53 & 212 \\
Sidorukun & 50 & 214 & 36 & 169 \\
Roomo & 57 & 229 & 44 & 176 \\
\hline
\end{tabular}

Table 1 indicates that the house connections at Singosari 2 and Singosari 3 have exceeded the design criteria: 213 people (61 connections) and 354 people (57 connections), respectively. These conditions are due to advantages of CWWTP known by the communities. Several programmes had been run by the communities that collaborated with facilitators.

Field observation indicated that the effluent from CWWTPs produced bad odors as the ventilation is not quite high. The ventilation at Singosari 1, Singosari 2, and Roomo are 3 meters high; but ventilation is found at Singosari 3. Bedilan CWWTP has 1-meter-high-vent while in Karangturi the vents are in every manhole. Domestic wastewater has high protein content; thus it is a major source of odor from decomposition process [19]. According to the report from the management, some solid waste has been found in inlet piping systems and makes wastewater flow from manhole.

The results from questionnaire indicated that $41,30 \%$ respondents agreed that the major problem in wastewater distribution systems is clogging. This results have been proven at some CWWTP like Roomo, Sidorukun, and Karangturi. The several problems in WWTP shown in Fig. 1.

\subsection{Process in CWWTP}

Laboratory results from the outlet of 7 CWWTP as compared to effluent quality standard of East Java Governor Regulation number 72/2013 are shown in Table 2 and Table 3. Table 2 indicates that the concentration of COD, BOD, and oil and grease from effluent of Singosari 1, Bedilan, and Roomo WWTP do not meet the standards. It indicates the biological process in CWWTP do not perform properly. Based on field observations, detergent (surfactant) are used too much as some dug wells have high hardness concentration. The hardness concentration of ground water in Singosari and Kebomas District is $643 \mathrm{mg} / \mathrm{l}$ and $400 \mathrm{mg} / \mathrm{l}$, respectively [20].

High concentration of hardness is highly associated of high consumption of detergent which also increase organic loading [21]. Inorganic matter such as dichromate also can cause high COD concentration in wastewater [22]. 
Table 2 - The comparison of the outlet of WWTP and wastewater quality standards

\begin{tabular}{crrrrr}
\hline \multirow{2}{*}{ WWTP location } & \multicolumn{5}{c}{ Parameter } \\
\cline { 2 - 6 } & pH & TSS & COD5 & BOD & Oil \\
\hline Singo1 & 7.45 & 96 & 430 & 51 & 24 \\
Bedilan & 7.60 & 24 & 355 & 45 & 80 \\
Roomo & 7.54 & 52 & 365 & 57 & 72 \\
Singosari 2 & 26 & 28 & - & - & - \\
Singosari 3 & 20 & 76 & - & - & - \\
Karangturi & 37 & 52 & - & - & - \\
Sidorukun & 41 & 64 & - & - & - \\
Standards & $6-9$ & 50 & 50 & 30 & 10 \\
\hline
\end{tabular}

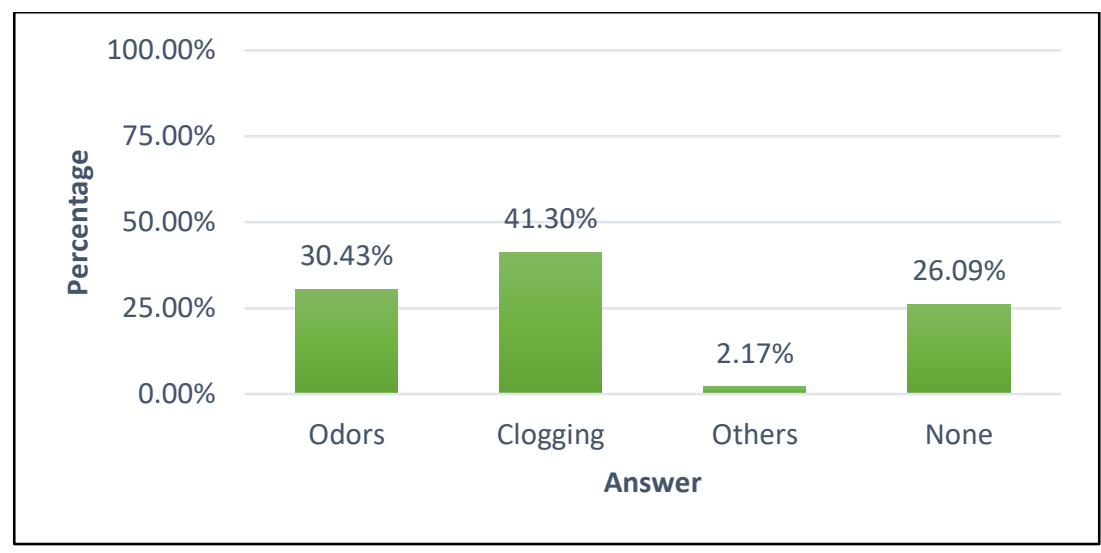

Fig. 1 - The most problems in WWTP

\subsection{Removal of COD, BOD, TSS and Oil and Grease}

Based on the laboratory results, it indicated that all of CWWTP complied with design criteria for BOD removal efficiency. Unfortunately, only Roomo CWWTP can comply with the design criteria due to high COD removal. COD removal in Roomo is 67,4\% and the design criteria based on Tchobanoglous et al., 2003 is betweem 65-90\%. Removal efficiency of oil and grease in Bedilan is only $13 \%$.

\subsection{BOD and COD Ratio}

Ratio BOD to COD is used to determine the biodegradability. The ratio of BOD to COD in Singosari 1, Bedilan, and Roomo are shown in Fig. 2. The ratio of BOD to COD in domestic wastewater should be between $0.3-0.8$ and $0.1-0.3$ for treated domestic wastewater [22]. Fig. 2 indicates that ratio of BOD to COD for Singosari 1, Bedilan, and Roomo are $0.55 ; 0.29 ; 0.27$, respectively. Therefore, the untreated wastewater can be processed biologically.

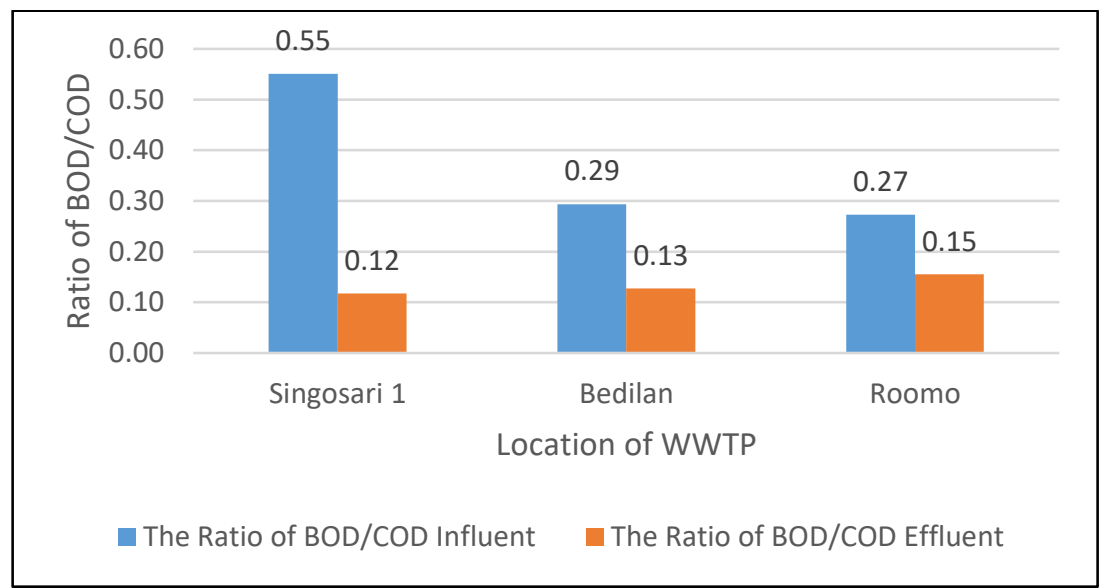

Fig. 2 - The BOD to COD ratio for inlet and outlet WWTP 


\subsection{Assessment of KPP}

KPP duties are [18]:

1. Arranging the work plan, operational and maintenance of CWWTP and wastewater distribution mechanism,

2. Collecting and managing funds for operational and maintenance costs that are derived from membership fees and others,

3. Operating and maintaining CWWTP including the sewer system,

4. Improving service quality and increasing number of house connections,

5. Conducting health campaign.

Duties and function of KPP based on the survey are shown in Fig. 3. It indicates that the respondent knowledge regarding duties and function of KPP is quite low

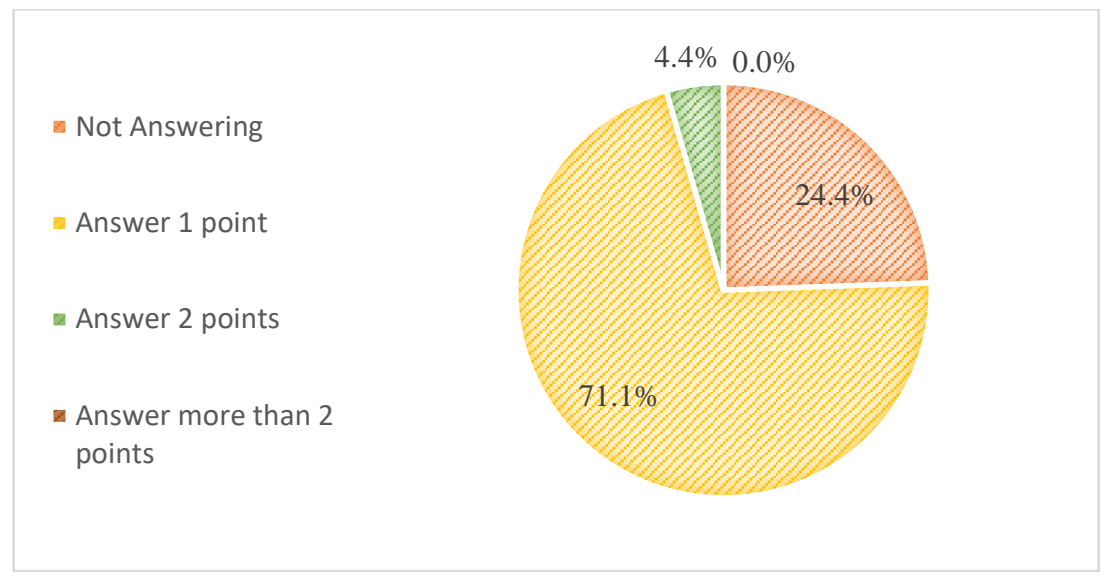

Fig. 3 - The respondents' knowledge level of duties and function as KPP

\subsection{Evaluation of organizational structure management}

Organizational structure of KPP consists of 6 members [18]. KPP of CWWTP is formed during community meeting of system users which the appointed committees are legalized by Head of the Village. Number of each KPP personnel is shown in Table 3.

Table 3 - The number of member in each KPP

\begin{tabular}{lc}
\hline \multicolumn{1}{c}{ Name of KPP } & $\begin{array}{c}\text { The number of member } \\
\text { (people) }\end{array}$ \\
\hline KPP Bulan Barat & 3 \\
KPP KarangturiPeduli & 9 \\
KPP TelagaAbadi & 5 \\
KPP TulusIkhlas & 9 \\
KPP Sri Rejeki & 7 \\
KPP Sidomakmur & 8 \\
KPP SumberRejeki & 9 \\
\hline
\end{tabular}

Table 3 shows the number of personnel in Roomo and Bedilan. Each division has its owned responsibility to avoid the overlap work. Any personnel in KPP has to collaborate to create an efficient KPP.

\subsection{Operation and maintenance of CWWTP}

Operation and maintenance in CWWTP are to keep the lifetime of the plants. Communal sanitation facilities should be supported by realistic operational and maintenance cost to provide sustainable services. KPP is expected to follow standard operational and procedure (SOP) for CWWTP. The monitoring frequency of CWWTP is shown in Fig. 4. 


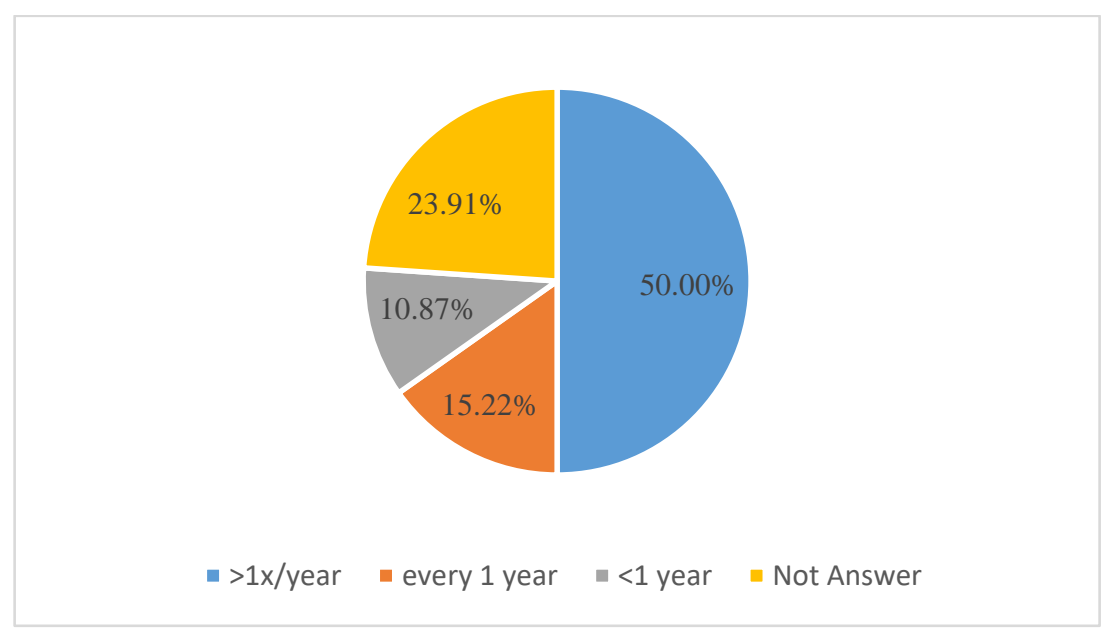

Fig. 4 - The monitoring frequency of WWTP

Fig. 4 shows that inspection frequency of CWWTP is $50 \%$ which means and it is conducted once a year. Based on the report from management, this monitoring was conducted by government agency while the SOP emphasized a strong involvement of the KPP.

\section{Conclusions}

1. CWWTPs in study area are quite good but the major problem in each CWWTP is the odor.

2. All of the CWWTPs comply with the design criteria for efficiency of BOD removal. Unfortunately, only Roomo can comply with the design criteria for efficiency of COD removal. COD removal in Roomo is $67,4 \%$.

3. The understanding of duties and responsibility of KPP is low as simply less information for village communities.

4. Severalpersonnels in Roomo and Bedilan are still in accordance with requirement of Ministry of Public Works.

\section{References}

1. United Nations. (2013). The Millenium Development Goals Report: 2013. (New York: United Nations).

2. M.S. Winters, A.G. Karim, and B. Martawardaya. (2014). Public Service Provision Under Conditions Of Insufficient Citizen Demand: Insights From The Urban Sanitation Sector In Indonesia. World Development, 60, 31-42.

3. UNICEF Indonesia. (2012). Ringkasan Kajian: Air Bersih, Sanitasi \& Kebersihan.

4. Presiden Decree. (2010). Presiden Decree No. 5 about National Medium Term Development Plant. (Jakarta: Government of Indonesia).

5. Strategi Sanitasi Kabupaten Gresik. (2015). Sanitation Strategies in Gresik District in 2011.

6. S. Yudo and R.H. Indriatmoko. (2006). Evaluasi Hasil Pembangunan Instalasi Pengolah Air Limbah Domestik Tipe Komunal Di Wilayah Kotamadya Jakarta Pusat. Jurnal Teknik Lingkungan, 166-173. Badan Pengkajian dan Penerapan Teknologi.

7. N. Windari. (2014). Implementation of Environmental Health Program at UPTD of Kari Kari District of Kuantan Singingi. Jurnal FISIP, 1(2), 1-26.

8. I.M.W. Wijaya and E.S. Soedjono. (2018). Domestic Wastewater in Indonesia: Challenge in The Future Related to Nitrogen Content. Geomate Journal, 15(47), 32-41.

9. A.Y. Katukiza, M. Ronteltap, C. Niwagaba, F. Kansiime, and P.N.L. Lens. (2010). Selection of sustainable sanitation technologies for urban slums - a case of Bwaise III in Kampala, Uganda. Sci Total Environ., (409) : 5262.

10. D. Mara, J. Dranger, N. Viet Anhc, A. Tonderski, H. Gulyas, and K. Tonderski. (2007). Selection of Sustainable Sanitation Arrangements. Water Policy, 9, 305-318.

11. Ministry of Public Works. (2017). Regulation of Ministry of Public Works No. 4 about Operation of Domestic Wastewater System. (Jakarta: Ministry of Public Works).

12. L. Sasse. (1998). Decentralized Waste Water Treatment in Developing Countries. DEWATS. (Bremen: Borda).

13. W.P. Barber and D.C. Stuckey. (1999). Use of The Anaerobic Baffled Reactor (ABR) for Wastewater Treatment: A Review. Wat. Res., 33(7), 1559-1578. (London: Elsevier Science Ltd.).

14. The Center Regulation Policy and Governance and Institute for Sustainable Future. (2015). Review of Regulatory Framework for Local Scale “Air Limbah”. (Sydney: Institute for Sustainable Futures, University of Technology Sydney). 
15. E.S. Soedjono, N. Fitriani, and I. M. W. Wijaya. (2017). Provision of Healthy Toilet for Low Income Community based on community empowerment in Kelurahan Kebonsari, Surabaya City, toward Indonesia Open Defecation Free (ODF) in 2019. AIP Conference Proceedings, 1903(1), pp. 040012.

16. Sudjana. (1996). Metoda Statistika Edisi Ke-6. (Bandung: Tarsito).

17. Ministry of Public Works. (2007). Regulation of Ministry of Public Works No. 18 about The Impelemtation of Water Supply. (Jakarta: Ministry of Public Works).

18. Program Nasional Pemberdayaan Masyarakat. (2013). Technical Guidelines for Operation and Maintenance of the Urban Sanitation Community-Based Society. (Jakarta: Ministry of Public Works).

19. Sugiharto. (1987). Dasar-Dasar Pengelolaan Air Limbah. (Jakarta: UI Press). 8-12, 27-31.

20. Q. Nugrahayu and A. Purnomo. (2013). Penurunan Kandungan Zat Kapur dalam Air Tanah dengan Menggunakan Filter Media Zeolit Alam dan Pasir Aktif Menjadi Air Bersih. Jurnal Teknik POMITS 2(2), ISSN: 2337-3539.

21. R. N. Sopiah. (1999). Pengelolaan Limbah Detergen Sebagai Upaya Minimalisasi Polutan di Badan Air dalam Rangka Pembangunan Berkelanjutan. (Bandung: BPPT).

22. G. Tchobanoglous, F.L. Burton, and H.D. Stensel. (2003). Wastewater Engineering: Treatment and Reuse, ${ }^{\text {th }}$. Medcalf and Eddy Inc. (New York: Mc Graw Hill Inc). 